\title{
Promoting Accurate Psychiatric Diagnosis in People with Intellectual/Developmental Disability
}

\author{
*Robert J Fletcher \\ Psychiatry of Intellectual Disability, National Association on Dual Diagnosis, USA
}

Submission: November 16, 2017; Published: December 08, 2017

*Corresponding author: Robert J Fletcher, Founder and CEO National Association on Dual Diagnosis NADD, Psychiatry of Intellectual Disability, New York, USA, Email: rfletcher@thenadd.org

\section{Opinion}

People with intellectual/developmental disabilities (IDD) experience high rates of psychiatric disorders. Based on patient charts form 30 states in the USA $(\mathrm{N}-13,466)$, the National Core Indicators has identified a rate of $55 \%$ of people with IDD have a co-occurring psychiatric disorder (National Core Indicators, 2016) [1]. Despite the common occurrence of psychiatric disorders in individuals with IDD, these disorders often evade proper identification. There are multiple reasons that arriving at an appropriate psychiatric diagnosis for an individual with IDD is challenging, but the welfare and quality of life of the individual depends upon an accurate diagnosis. Quite simply, accurate diagnosis is required for effective treatment which in turn leads to improved outcomes and thus enables a better quality of life. Individuals with IDD experience difficulties in receptive and expressive language to varying degrees. Mild limitations in receptive and expressive language make it difficult, and severe limitations may make it impossible, for people with IDD to articulate such abstract or global concepts as depressed mood or to communicate subtle differences among emotional or motivational states. The clinician may also find that some individuals with IDD seek to hide their disabilities and assume a "cloak of competence," which results in the individual not being forthcoming with respect to self-descriptions. The individual may also try to please the evaluator by providing inaccurate or false answers. The symptoms of a variety of psychiatric disorders are often expressed differently in people with IDD. In some cases, the diagnosis of IDD predisposes practitioners to overlook the presence of psychopathology and to attribute unusual or anomalous behavior to the IDD. Clinicians often lack training in identifying psychopathology in individuals with IDD and feel unprepared to meet the challenges involved.

Help is available. The efforts of more than 100 experts from around the world have combined to produce Diagnostic Manual-Intellectual Disability: A Textbook of Diagnosis of Mental Disorders in Persons with Intellectual Disability, second edition [2]. Using an expert consensus model and extensive review of the research literature, this book provides information about obtaining a valid DSM-5 diagnosis for individuals with IDD. There is a chapter on conducting an assessment, and another discusses the behavioral phenotypes of twelve genetic syndromes associated with IDD. The following chapters address all of the disorders that are contained in the DSM-5. Discussion includes etiology and pathogenesis as well as how the disorder manifests in individuals with IDD. Diagnostic tables offer the clinician assistance in making an accurate diagnosis, including the use of symptom equivalents, changes in symptom count or age of onset, and the use of respondents rather than self-report.

\section{References}

1. National Core Indicators (2016) Mental illness or psychiatric diagnosis.

2. Fletcher RJ, Barnhill J, Cooper SA (2016) Diagnostic manual-Intellectual disability a textbook of diagnosis of mental disorders in persons with intellectual disability ( $2^{\text {nd }}$ edn) DM-ID-2. NADD Press, Kingston, New York, USA. 
This work is licensed under Creative Commons Attribution 4.0 Licens

DOI: 10.19080/GJIDD.2017.04.555629
Your next submission with Juniper Publishers will reach you the below assets

- Quality Editorial service

- Swift Peer Review

- Reprints availability

- E-prints Service

- Manuscript Podcast for convenient understanding

- Global attainment for your research

- Manuscript accessibility in different formats

( Pdf, E-pub, Full Text, Audio)

- Unceasing customer service

Track the below URL for one-step submission

https://juniperpublishers.com/online-submission.php 